\title{
Vision Zero: from accident prevention to the promotion of health, safety and wellbeing at work
}

\author{
Zwetsloot GIJM ${ }^{1}$, Leka $\mathrm{S}^{2}$, Kines $\mathrm{P}^{3}$ \\ Published in: Policy and Practice in Health and Safety, 15, (1), 1-13. \\ Accepted 16 March 2017.
}

\begin{abstract}
There is growing attention in industry for the Vision Zero strategy, which in terms of workrelated health and safety is often labelled as Zero Accident Vision or Zero Harm. The consequences of a genuine commitment to Vision Zero for addressing health, safety and wellbeing and their synergies are discussed. The Vision Zero for work-related health, safety and wellbeing is defined as the assumption that all accidents, harm and diseases are preventable. Implementation of Vision Zero is a process - rather than a target, and healthy organisations make use of a wide range of options to facilitate this process. There is sufficient evidence that fatigue, stress, and work organisation factors are important determinants of safety behaviour and safety performance. Even with a focus on preventing accidents these additional factors should also be addressed. A relevant challenge is the integration of the Vision Zero into broader business policy and practice. There is a continued need more empirical research in this area.
\end{abstract}

\footnotetext{
${ }^{1}$ Director of Gerard Zwetsloot Research \& Consultancy and honorary professor at the University of Nottingham, Centre for Organisational Health and Development

${ }^{2}$ Professor at the Nottingham University, Centre for Organisational Health and Development

${ }^{3}$ Senior researcher at the National Research Centre for the Working Environment, Division of Safety Research, National Research Centre for the Working Environment,
} 


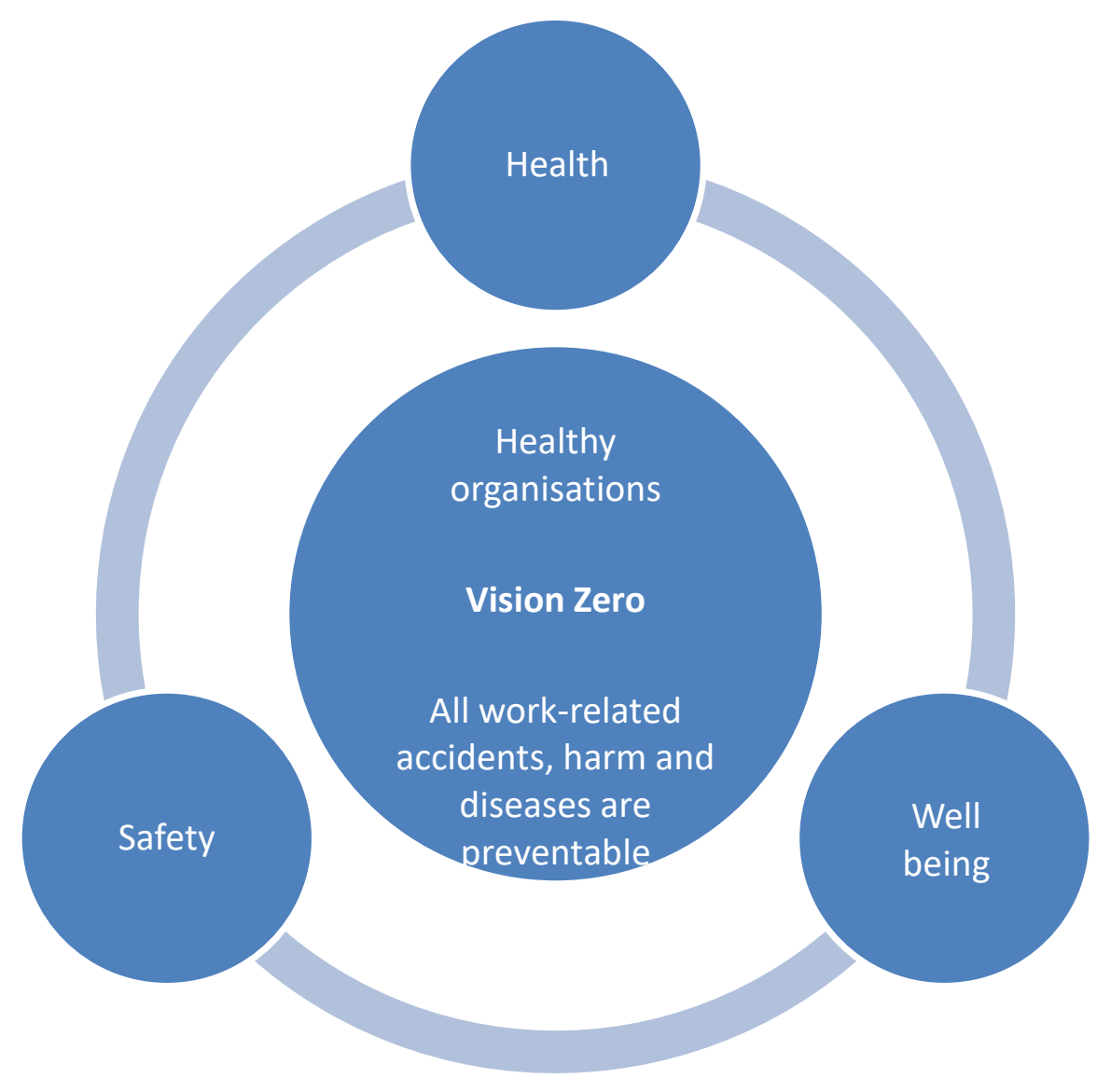

Keywords:

Zero Accidents, Zero Harm, psychosocial factors, safety culture, prevention culture

\section{Introduction}

The Zero Accident Vision (ZAV) is based on the assumption that all accidents are preventable. ZAV is then the ambition and commitment to create and ensure safe work and prevent all accidents in order to achieve safety excellence (Zwetsloot et al., 2017a, b). This is a high ambition and it sometimes gives rise to the misunderstanding that ZAV focuses on the 'goal' of zero accidents, rather than on a 'journey' and a 'process' of creating safe work (safety excellence). Zwetsloot et al. (2013a) called for more (empirical) research into the practices and perspectives of such commitments for improving safety. They stated that ZAV was developed in industry, and needed more attention from safety researchers. In this paper we want to focus on the broader Vision Zero (VZ), which addresses not only safety but also (occupational) health and wellbeing, which is often associated with the Zero Harm (ZH) concept. We also focus on the challenges companies may face to keep ZAV or VZ 'alive' in the long run, also when the need to improve health, safety and wellbeing (HSW) seems less 
urgent. The latter is closely related to the question of how to sustain VZ as part of the business strategy, in order to prevent it from becoming a new, broader occupational safety and health silo.

The expression 'health and safety', or Occupational Safety and Health (OSH) is often used by people and organisations to mainly address (occupational) safety concerns (Leka et al., 2016); their attention to work-related health and wellbeing is often limited to hazards and associated risks that stem, like safety risks, predominantly from technology related aspects of production processes, such as the design of technical installations and workplaces. Often there is less organisational and systematic attention paid to health compared to safety, while psychosocial risks and well-being at work often remain out of scope (Bergh et al., 2014a; Leka et al., 2015). It is not known to what degree this bias towards safety is also found in companies that have committed themselves to $\mathrm{ZH}$, which in principle seems to include health. The impression however, is that many $\mathrm{ZH}$ companies that already have developed a high degree of risk control in the area of safety, still have much to gain in the areas of health and well-being.

In this paper the Vision Zero for health, safety and wellbeing is based on the assumption that all accidents, harm and work-related diseases are preventable. VZ for HSW is then the ambition and commitment to create and ensure safe and healthy work and to prevent all accidents, harm and work-related diseases in order to achieve excellence in HSW. VZ should be understood as a journey, a process towards the ideal, which is usually expressed in the terms 'zero accidents' (for safety only) or ZH (ideally for safety, health and wellbeing). VZ is also a value-based vision implying that work should not negatively affect workers' HSW, and if possible, should help them maintain or improve their HSW and develop their selfconfidence, competences and employability.

The call for more research into ZAV (Zwetsloot et al., 2013a) generated enthusiasm and was followed up by the publication of some empirical research, but also raised criticism. As there are many similarities between ZAV and VZ, part of the criticism explicitly refers to the broader concept of $\mathrm{ZH}$. We will therefore first provide a concise overview and evaluation of raised criticism. 


\section{Criticism of the Zero Accident Vision and Zero Harm}

Several critical papers on ZAV or ZH have been published since 2013. The main criticisms are: (1) that ZAV is unrealistic and naïve, and denies the realities of risk (implying uncertainties, human limitation, and learning by mistake, Long 2012, Sharman 2014); (2) ZAV leads to more bureaucratic safety systems and bureaucratic accountability (Dekker, 2014 a, b, d); and (3) ZAV leads to a focus on very minor risks (Sharman, 2014), associated with overspending of investigation resources (Dekker, 2014b). The critics also state that ZAV leads to a safety culture of scepticism, cynicism, underreporting, lack of debate, fear of openness, a nonlearning climate (Long, 2012), intolerance (Sharman, 2014), stigmatisation of workers involved in incidents (Dekker, 2014b), and a punitive mind-set (Long, 2012). According to the critics, the focus in ZAV is on attaining zero injury rates, which may lead to underreporting (Sharman, 2014), and trickery and fraud with numbers (Dekker et al., 2015; Dekker and Pitzer, 2015; Dekker, 2014b). For a more in-depth overview, see Zwetsloot et al. (2017a).

According to Zwetsloot et al. (2017a), part of the criticism seems to be based on the assumption that ZAV committed companies are trying harder to do the same old safety things, i.e. to make more safety procedures (systems associated with greater bureaucracy), and to be stricter and more punitive towards unsafe behaviour. If that assumption is right, the critics are right. But this is not what the empirical studies of VZ committed companies published so far confirm (Young, 2012; Twaalfhoven and Kortleven, 2016; Zwetsloot et al., 2017b).

The critics assume that ZAV (or ZH) companies have only three options to realise their ambition: stricter control through (bureaucratic) procedures, stricter behavioural control (or error prevention), and fraud with numbers (Dekker 2014 a, c, Long 2012, Sharman 2014). In reality, the limited empirical research into ZAV/VZ companies clarified that these companies realise that ZAV is based on a different mind-set, requiring a long-term process, and that healthy organisations make use of a wide range of traditional and innovative options to facilitate the ZAV process (Zwetsloot et al., 2017 a, b). For instance, developing a 'commitment strategy' for safety, integrating it into business development, using technological and social innovations, developing a learning safety culture, etc.

ZAV committed companies explored innovative ways to improve safety (see also Young, 2014), and endeavoured to develop a learning-driven safety culture. Instead of stricter control and more sanctions towards unsafe behaviour, there was more empowerment than in other safety frontrunner firms. Managers asked questions in order to trigger reflection and dialogue, instead of giving orders and referring to existing procedures (Zwetsloot et al., $2017 \mathrm{a}, \mathrm{b})$. 
The empirical results so far show that ZAV implementation often leads to significant safety improvements (e.g. Young., 2014; Zwetsloot et al., 2017a), thereby being keen to make use of technical and social innovations (Young, 2014). Companies and their personnel see ZAV as a journey driven by genuine long-term commitment (Young, 2014; Twaalfhoven and Kortleven, 2016; Koivupalo, 2015; Zwetsloot et al., 2017a) that does not lead to more bureaucracy. Instead, it leads to higher worker commitment and more empowerment (Zwetsloot et al., 2017b), to managers giving safety very high priority in daily practice, to the encouragement of participation and learning, and a culture that has more characteristics of a 'just culture' than is found in non-ZAV frontrunner firms (Zwetsloot et al., 2017b).

In any case, criticism should not overshadow the many good practices found in the empirical studies so far. All in all, an evaluation of the criticism published so far underlines the earlier Zwetsloot et al. (2013a) call for more research into the industrial practice of ZAV (or ZH) implementation.

It is to be noted that the critics of ZAV and ZH seem to have a very strong bias towards safety. In fact in their publications, ZH is almost equal to zero accidents (e.g. Dekker 2014, a, b, c; Long, 2012). They assume that the only reason for adopting zero accidents or harm is to reduce loss time incidents (LTI's) to zero (they see it as a goal, not as a process), which is a very limited interpretation of $\mathrm{ZH}$. In addition, they have not seriously addressed the ambitions in the areas of health and wellbeing.

The critics might be particularly negative about VZ, as they focus only on the unproductive impacts of approaches that are based on a misunderstanding of VZ. However, the criticisms they offer are helpful for understanding the pitfalls of VZ when applied incorrectly. Table 1 provides an overview of some potential pitfalls for companies that strive to achieve zero accidents.

Table 1 around here

Table 1: Pitfalls when considering Vision Zero 


\begin{tabular}{|l|l|}
\hline Vision Zero used inappropriately & Vision Zero used appropriately \\
\hline $\begin{array}{l}\text { Applying Vision Zero as a target and making } \\
\text { people accountable for realising it (perhaps } \\
\text { even strengthened by economic incentives) }\end{array}$ & $\begin{array}{l}\text { It is a process that requires commitment } \\
\text { from all leaders and workers in an } \\
\text { organisation }\end{array}$ \\
\hline $\begin{array}{l}\text { Focusing strongly on incident rates (and } \\
\text { other lagging indicators) }\end{array}$ & Using leading indicators \\
\hline $\begin{array}{l}\text { Assuming that more safety rules, } \\
\text { management systems and behavioural } \\
\text { control will help to go from good to } \\
\text { excellent safety performance }\end{array}$ & $\begin{array}{l}\text { Focus on leadership, being innovative and } \\
\text { learning }\end{array}$ \\
\hline $\begin{array}{l}\text { Assuming that one approach is able to } \\
\text { improve different types of safety (e.g. } \\
\text { process and personal safety) }\end{array}$ & $\begin{array}{l}\text { Using a variety of approaches and adapting } \\
\text { them where appropriate }\end{array}$ \\
\hline
\end{tabular}

We consider ZAV and $\mathrm{ZH}$ companies as companies that are 'innovating' their approaches with the intention to achieve excellence in safety or in HSW. This paper will therefore discuss the consequences of a genuine commitment to $\mathrm{ZH}$ for developing an integrated, balanced approach to HSW at work, realising synergies in HSW.

\section{Vision Zero for health, safety and wellbeing at work}

HSW at work are often parallel silos both in organisational practice, and in research communities. There are different foci that have emerged in the various silos, as well as several frequently found misunderstandings which hinder mutual understanding and cooperation in these key areas. Safety experts tend to regard psychosocial risks (let alone positive psychology) as not very relevant for safety, and as a 'very soft' area with a lack of hard evidence. A topic like 'personal resources' (an important area in the Job Demands and Resources model referring to self-efficacy, self-esteem and optimism) is likely to be associated by safety experts with the 'accident prone' theory (referring to personal characteristics in general) (Dahlbäck, 1991), which goes back to 1926, but which still remains controversial (Burnham, 2009). See also Christian et al. (2009) for a good meta-analysis of the role of personal factors in workplace safety. 
Experts in well-being at work tend to think that safety is a 'hard', technology dominated area, where simple 'mono-causal' factors lead to incidents (wellbeing being multi-causal). However, many safety experts nowadays focus strongly on safety culture and/or safety climate (e.g. Griffin et al., 2016; Leitão et al., 2016; Petitta et al., 2017; Zohar, 2014), and on interventions to improve safety awareness and organisational and behavioural change, subjects that are certainly not 'hard' nor 'mono-causal'.

It is important to note that $\mathrm{ZH}$ implies the control (or reduction) of occupational risks stemming from different types of hazards. Safety hazards stem mainly from energy intensive processes or products that imply the potential of acute liberation of energy injuring people and damaging the work environment, or they stem from the potential of loss of containment of (acute) toxic materials. Traditional occupational health hazards stem from various (chronic) exposures to physical, chemical and biological agents, as well to physical strain and the burden of unfavourable postures, movements, etc. Psychosocial hazards stem from work organisation or negative interpersonal interactions. Although there are many interrelationships between these various types of hazards, the different types of hazards require also different methods for risk assessment and different types of control measures. This is also true within the safety domain, as we now know that a focus on prevention of personal risks does not help to reduce process safety risks (Baker, 2007), and a focus on minor personal safety risks does not automatically help reduce severe personal risks (Mendeloff and Burns, 2013).

While the focus in the area of psychosocial risks, or positively formulated wellbeing at work, is strongly on work organisation and interpersonal interactions, in the area of safety there is little empirical evidence regarding work organisation (some exceptions are Parker et al., 2001; Laschinger et al., 2006). The psychological perspective on safety seems to be dominated by (safe and unsafe) behaviour and safety culture/climate. While in the area of wellbeing growing attention has been placed on the importance of organisational culture (see for example Dollard and Bakker, 2010; Dollard, 2007; Zwetsloot and Leka, 2010).

\subsection{Commonalities of safety and wellbeing}


Safety and wellbeing likely have more in common than many would expect. In both areas, design and management challenges are important. The control of deviations in work processes is a shared interest. There are many similarities between the promotion of health and wellbeing and safety promotion. Business ethics are relevant for safety and for wellbeing, with many recent challenges, e.g. the impact of globalisation on the (changing) workplace, the impacts of continuous cost reductions, and the focus on core activities and outsourcing of all non-core activities. Positive psychology is not only relevant for 'work engagement', but is also likely to be relevant for safety promotion (Nahrgang et al., 2012; Mathisen \& Bergh, 2016). In the safety domain, the increasing attention to the concept of 'resilience' has also led to a positive safety concept 'Safety 2' (Hollnagel, 2014). In the area of resilience engineering there is now a growing interest in how 'resources' help to master deviations (Grøtan et al., 2016). Other common bases for safety and wellbeing are: (1) control of (work) processes and dealing with deviations, (2) improving accuracy, avoiding human error, and (3) proactive approaches to new developments, including reorganisations and outsourcing, increasing flexibility, job insecurity etc..

Fitness for the job is a concept that also bridges the two areas. The IAEA (2016) mentions 'fitness for duty' as one of the areas relevant for safety culture. The physical and mental fitness of the workforce is key to alertness and risk awareness. Traditional aspects thereof concern the (non) use of alcohol and drugs, and fatigue, but increasingly this is seen in a broader perspective, paying also attention to the prevention of stress and burnout, and the promotion of healthy lifestyles.

Interfaces between steps in the production process are often problematic in safety (potentially causing communication problems and control challenges); in socio-technical theories these are known to be a source of production problems (quality), and to be a source of stress. The socio-technical approach is therefore to reduce the division of labour as much as possible, preferring simple organisations with complex jobs, over complex organisations with simple jobs. See Grote and Kunzler $(1996,2000)$ for socio-technical approaches to safety. 
From the perspective of credibility for the employees the two areas (safety and wellbeing) are also closely associated. Credibility, taking care of the safety of people also implies, often implicitly, taking care of their health, and vice versa. The different traditions and foci imply complementarities and opportunities for synergies. Several concepts and models that have been developed and are based on considerable evidence in one area, also seem relevant for the other area, e.g. on job design and work organisation (wellbeing) (e.g. Leka et al. 2008) versus management systems, increasing risk awareness and safety culture (Edwards et al., 2013; Clarke, 2006). This is also evident in the content of developed standards like OHSAS (BSI, 2007) that focuses on OSH management systems, and PAS1010 (BSI, 2011) that focuses on the management of psychosocial risks in the workplace.

While safety experts focus on the organisational level for psychosocial aspects of safety (safety culture and climate), psychosocial experts in the areas of health and wellbeing at work focus on work organisation, job content, demands and resources. These different traditions seem highly complementary and suggest a potential for important synergies.

\subsection{Fatigue and safety}

Irregular working hours and over-time work may result in chronic fatigue, which can lead to decreased concentration and cognitive failure during work (Akerstedt et al., 2002; Williamson, 2011). Dembe et al. (2005) report an increase in occurrence of occupational accidents by $23 \%$ among employees working at least 60 hours per week. Lamond and Dawson (1999) showed that that moderate levels of fatigue may produce performance impairment equivalent to or greater than those observed at levels of alcohol intoxication deemed unacceptable when driving, working and/or operating dangerous equipment. According to Chan (2011) fatigue is the most critical accident risk factor in oil and gas construction.

\subsection{Stress and safety}

Flin et al. (2008) described how stress can impact workers' performance negatively in terms of efficiency and accuracy, and it has also been associated with lower levels of work situation awareness for drilling personnel on oil and gas installations (Sneddon et al., 2013). Mathisen 
and Bergh (2016) found a positive association between emotional exhaustion and action errors/violations, and a negative relationship between engagement and action errors/violations.

Stress has been linked with poor sleep quality, excessive drinking, feeling depressed, feeling anxious, jittery, inattentive behaviour, which may result in momentarily distraction, human error and/or failure in normal activities (Leka \& Jain, 2010; Mearns et al., 2001). Larsson (2003) saw another synergy: according to him prevention of accidents and injuries is also an important strategy to prevent post-traumatic stress.

Mearns et al. (2001) showed that the variable most likely to predict accidents and near misses on an oil installation is 'unsafe work practices'. The number one predictor of 'unsafe work practices' was employees having a perception of 'high production pressure'. It was the feeling of stress that contributed to performance issues in safety-critical operations. Stress as a result of high production pressure was directly related to work practices. It is therefore easy to see a correlation between being stressed as a result of perceived production pressures and making critical errors at work.

Goldenhar et al. (2003) showed a correlation between several stressors (e.g. job demands, job control, job uncertainty, training, exposure hours, and job tenure) and safe work practices in construction, and Glasscock et al. (2006) found similar results in farming. Bergh et al. (2014b) found a correlation between psychosocial risk factors and hydrocarbon leaks on offshore platforms, whereas Ramvi (2003) showed a correlation between the quality of the psychosocial work environment and commitment to safety at work at two different oil installations in the North Sea.

\subsection{Work organisation and safety}

Given the relevance of stress (prevention) for safety, it is not surprising that there is also considerable evidence that work organisation factors are important for safety. Deviations in production process are known to be a potential trigger for the causation of accidents. In psychosocial research, deviations are regarded as 'demands' on the worker to deal with (requiring sufficient autonomy / decision latitude) (e.g. Karasek, 1979; Bergh et al., 2016). 
Actions to prevent accidents go hand in hand with making operations more reliable, which also have an impact on workers' health and well-being.

The relevance of work organisation factors for safety are also addressed in several accident investigation models and methods. For example, the TRIPOD methodology of incident investigation (Groeneweg, 1994) comprises 'error enforcing conditions' as one of the eleven basic risk factors that can underlie many accidents. The great body of knowledge on the importance of decision latitude (autonomy), social support etc. that is available in the area of psychosocial risk management, has now also been proven to be relevant for safety (e.g. to reduce human error, etc.). A meta-analysis by Nahrgang et al. (2011) showed that job demands and resources relate to safety outcomes.

\section{Broadening the six innovative perspectives}

The application of presently available (evidence based) methods and tools can help most companies to realise important steps towards genuine Zero. However, VZ is also paradoxical, and it will also require organisations to explore and identify new paths. In the $2^{\text {nd }} Z A V$ discussion paper (Zwetsloot et al., 2017a), an important discussion is centred on a table that clarifies six innovative perspectives for ZAV. This Table can be adapted to VZ perspectives promoting $\mathrm{ZH}$ broadly, encompassing HSW. Table 2 is a first attempt towards this perspective.

Table 2: around here

Table 2: Zero Harm for health, safety and wellbeing - six innovative perspectives (elaborating on Zwetsloot et al., 2017a)

\begin{tabular}{|l|l|l|l|}
\hline ZAV Theme & $\begin{array}{l}\text { Traditional safety } \\
\text { approach } \\
\text { (accident prevention) }\end{array}$ & Zero Accident Vision & $\begin{array}{l}\text { Zero Harm for health, } \\
\text { safety and wellbeing } \\
\text { (HSW) }\end{array}$ \\
\hline $\begin{array}{l}\text { Commitment } \\
\text { strategy }\end{array}$ & Safety control strategy & Safety commitment strategy & $\begin{array}{l}\text { HSW is a long-term } \\
\text { commitment strategy }\end{array}$ \\
\cline { 2 - 4 } & Safety is a priority & Safety is a value & HSW is a value \\
\hline
\end{tabular}




\begin{tabular}{|c|c|c|c|}
\hline & $\begin{array}{l}\text { Safety ( } 0 \text { accidents) is } \\
\text { an (unrealistic) goal }\end{array}$ & Safety is a process, a journey & $\mathrm{HSW}$ is a process, a journey \\
\hline & $\begin{array}{l}\text { Safety and health are in } \\
\text { practice two distinct } \\
\text { worlds }\end{array}$ & $\begin{array}{l}\text { Safety and health are } \\
\text { ethically and practically } \\
\text { closely interconnected }\end{array}$ & $\begin{array}{l}\text { Safety, health and wellbeing } \\
\text { are ethically and practically } \\
\text { closely interconnected }\end{array}$ \\
\hline \multirow[t]{5}{*}{$\begin{array}{l}\text { A way of } \\
\text { doing } \\
\text { business }\end{array}$} & $\begin{array}{l}\text { Safety improvements } \\
\text { stem from safety } \\
\text { programs }\end{array}$ & $\begin{array}{l}\text { Safety is an integrated part } \\
\text { of doing business }\end{array}$ & $\begin{array}{l}\text { HSW is an integrated part of } \\
\text { doing business }\end{array}$ \\
\hline & $\begin{array}{l}\text { Safety is mainly a } \\
\text { tactical and operational } \\
\text { challenge }\end{array}$ & $\begin{array}{l}\text { Safety is a strategic } \\
\text { challenge }\end{array}$ & $\mathrm{HSW}$ is a strategic challenge \\
\hline & Risk management & $\begin{array}{l}\text { Safety leadership and } \\
\text { business excellence }\end{array}$ & $\begin{array}{l}\text { HSW leadership and } \\
\text { business excellence }\end{array}$ \\
\hline & $\begin{array}{l}\text { Safety is perceived as a } \\
\text { cost factor }\end{array}$ & $\begin{array}{l}\text { Safety is perceived as an } \\
\text { investment }\end{array}$ & $\begin{array}{l}\text { HSW is perceived as a long- } \\
\text { term investment }\end{array}$ \\
\hline & $\begin{array}{l}\text { Safety is only relevant } \\
\text { internally (and for the } \\
\text { authorities) }\end{array}$ & $\begin{array}{l}\text { Safety is also relevant for } \\
\text { business partners and } \\
\text { external stakeholders }\end{array}$ & $\begin{array}{l}\text { HSW is also relevant for } \\
\text { business partners and } \\
\text { external stakeholders }\end{array}$ \\
\hline Innovation & $\begin{array}{l}\text { The workplace is more } \\
\text { or less a static } \\
\text { environment wherein } \\
\text { safety management will } \\
\text { lead to continuous } \\
\text { improvement }\end{array}$ & $\begin{array}{l}\text { The workplace is a dynamic } \\
\text { environment wherein } \\
\text { technological and social } \\
\text { innovations are important for } \\
\text { significant improvements in } \\
\text { safety }\end{array}$ & $\begin{array}{l}\text { The workplace is a dynamic } \\
\text { environment wherein } \\
\text { technological and social } \\
\text { innovations are important for } \\
\text { significant improvements in } \\
\text { HSW }\end{array}$ \\
\hline \multirow[t]{5}{*}{$\begin{array}{l}\text { Prevention } \\
\text { culture }\end{array}$} & Preventing accidents & Creating safety & $\begin{array}{l}\text { Creating safety, health and } \\
\text { well-being at work }\end{array}$ \\
\hline & $\begin{array}{l}\text { Compliance }-{ }^{'} \text { We have } \\
\text { to' (external motivation) }\end{array}$ & $\begin{array}{l}\text { Participation - 'We want to' } \\
\text { (intrinsic motivation) }\end{array}$ & $\begin{array}{l}\text { Participation - 'We want to' } \\
\text { (intrinsic motivation) }\end{array}$ \\
\hline & Incidents are failures & $\begin{array}{l}\text { Incidents are opportunities } \\
\text { for learning }\end{array}$ & $\begin{array}{l}\text { HSW events (incidents, } \\
\text { cases) are opportunities for } \\
\text { learning }\end{array}$ \\
\hline & $\begin{array}{l}\text { Safe behaviour is } \\
\text { desirable }\end{array}$ & Safe behaviour is the norm & $\begin{array}{l}\text { HSW promoting behaviour } \\
\text { is the norm }\end{array}$ \\
\hline & $\begin{array}{l}\text { Workers' behaviour } \\
\text { (human error) are part } \\
\text { of the problem }\end{array}$ & $\begin{array}{l}\text { Workers are empowered to } \\
\text { come up with solutions - } \\
\text { they are part of the solution }\end{array}$ & $\begin{array}{l}\text { Workers are empowered to } \\
\text { come up with solutions - } \\
\text { they are part of the solution }\end{array}$ \\
\hline
\end{tabular}




\begin{tabular}{|c|c|c|c|}
\hline & $\begin{array}{l}\text { Safety is designed or } \\
\text { prescribed by experts }\end{array}$ & $\begin{array}{l}\text { Safety is co-created by } \\
\text { experts and all members of } \\
\text { the organisation (having a } \\
\text { questioning and learning } \\
\text { approach) }\end{array}$ & $\begin{array}{l}\text { HSW is co-created by } \\
\text { experts and all members of } \\
\text { the organisation (having a } \\
\text { questioning and learning } \\
\text { approach) }\end{array}$ \\
\hline & $\begin{array}{l}\text { Focus on management } \\
\text { systems }\end{array}$ & $\begin{array}{l}\text { Focus on culture and } \\
\text { learning }\end{array}$ & $\begin{array}{l}\text { Focus on culture and } \\
\text { learning }\end{array}$ \\
\hline & $\begin{array}{l}\text { Safety culture is } \\
\text { important }\end{array}$ & $\begin{array}{l}\text { Safety culture and 'just' } \\
\text { culture are important }\end{array}$ & $\begin{array}{l}\text { HSW promoting a 'just' } \\
\text { culture are important }\end{array}$ \\
\hline & $\begin{array}{l}\text { Focus on accident } \\
\text { prevention }\end{array}$ & $\begin{array}{l}\text { Focus on accident prevention } \\
\text { and safety promotion }\end{array}$ & $\begin{array}{l}\text { Focus on prevention and the } \\
\text { promotion of HSW in work } \\
\text { and life }\end{array}$ \\
\hline $\begin{array}{l}\text { Ethics and } \\
\text { CSR }\end{array}$ & $\begin{array}{l}\text { Safety management is } \\
\text { always rational }\end{array}$ & $\begin{array}{l}\text { Safety management is } \\
\text { rational but also founded on } \\
\text { ethics }\end{array}$ & $\begin{array}{l}\text { HSW leadership is rational } \\
\text { but also founded on ethics }\end{array}$ \\
\hline & $\begin{array}{l}\text { Safety is associated with } \\
\text { prescriptions, paper } \\
\text { work, and owned only } \\
\text { by a few champions }\end{array}$ & $\begin{array}{l}\text { Safety is inspiring, 'alive' } \\
\text { and 'owned' by all members } \\
\text { of the organisation }\end{array}$ & $\begin{array}{l}\text { HSW is inspiring, 'alive' } \\
\text { and 'owned' by all members } \\
\text { of the organisation }\end{array}$ \\
\hline & Transactional leadership & Transformational leadership & $\begin{array}{l}\text { Transformational leadership } \\
\text { also paying attention to job } \\
\text { demands and resources }\end{array}$ \\
\hline & $\begin{array}{l}\text { Safety policy implicitly } \\
\text { based on values }\end{array}$ & $\begin{array}{l}\text { Safety policy explicitly based } \\
\text { on values }\end{array}$ & $\begin{array}{l}\text { HSW policy explicitly based } \\
\text { on values }\end{array}$ \\
\hline $\begin{array}{l}\text { Networking } \\
\text { and co- } \\
\text { creation }\end{array}$ & $\begin{array}{l}\text { Safety improvement is } \\
\text { triggered by internal } \\
\text { processes (Plan, Do, } \\
\text { Check, Act) }\end{array}$ & $\begin{array}{l}\text { Safety improvement is } \\
\text { triggered also by learning } \\
\text { from the experiences of } \\
\text { others in and outside the } \\
\text { organisation }\end{array}$ & $\begin{array}{l}\text { HSW improvement is } \\
\text { triggered also by learning } \\
\text { from the experiences of } \\
\text { others in and outside the } \\
\text { organisation }\end{array}$ \\
\hline & $\begin{array}{l}\text { Benchmarking on } \\
\text { lagging indicators (like } \\
\text { injury rates) }\end{array}$ & $\begin{array}{l}\text { Benchmarking on leading } \\
\text { indicators and good practices }\end{array}$ & $\begin{array}{l}\text { Benchmarking on leading } \\
\text { indicators and good practices }\end{array}$ \\
\hline & $\begin{array}{l}\text { Safety improvement is } \\
\text { triggered by best } \\
\text { practices in the sector }\end{array}$ & $\begin{array}{l}\text { Safety improvement is } \\
\text { triggered by adopting and } \\
\text { adapting good practices from } \\
\text { other (ZAV) organisations }\end{array}$ & $\begin{array}{l}\text { HSW improvement is } \\
\text { triggered by adopting or } \\
\text { adapting good practices from } \\
\text { other (VZ) organisations and }\end{array}$ \\
\hline
\end{tabular}




\begin{tabular}{|l|l|l|l|}
\hline & & and sectors & sectors \\
\hline
\end{tabular}

The six innovative perspectives included in Table 2 can be further explored making use of several relevant concepts and theories. An overview thereof is provided in Table 3.

Table 3 around here

Table 3: Vision Zero for health, safety and well-being - six innovative perspectives and associated concepts and theories

\begin{tabular}{|c|c|c|}
\hline The innovative perspectives & Relevant concepts and theories & Selection of key eferences \\
\hline \multirow[t]{2}{*}{ A commitment strategy } & $\begin{array}{l}\text { Commitment strategy for high } \\
\text { performance }\end{array}$ & Beer 2009 \\
\hline & $\begin{array}{l}\text { Intrinsic motivation and self- } \\
\text { determination theory }\end{array}$ & $\begin{array}{l}\text { Ryan \& Deci } 2000 \\
\text { Deci \& Ryan } 2008\end{array}$ \\
\hline \multirow[t]{3}{*}{ A way of doing business } & Goal setting theory & Locke \& Latham 2002 \\
\hline & Transformational leadership & Barling et al. 2002 \\
\hline & Mainstreaming $\mathrm{OSH}$ & EU OSHA 2010 \\
\hline \multirow[t]{5}{*}{ Innovation } & Workplace innovation & $\begin{array}{l}\text { Eeckelaert et al. } 2012 \\
\text { Oeij et al. (in press, 2017) }\end{array}$ \\
\hline & Resilience Engineering & Hollnagel et al. 2006 \\
\hline & High Reliability Organisation & $\begin{array}{l}\text { Roberts } 1990 \\
\text { Weick \& Sutcliffe } 2007\end{array}$ \\
\hline & Inherently Safer Production & Zwetsloot \& Ashford 2003 \\
\hline & Innovation diffusion theory & Rogers 1993 \\
\hline Prevention culture & Prevention culture & $\begin{array}{l}\text { Eichendorf \& Bollmann } \\
\text { 2014; Salminen 2015: 2nd } \\
\text { Strategy Conference 2011; } \\
\text { WSH } 2012\end{array}$ \\
\hline \multirow[t]{3}{*}{ Ethics and CSR } & Institutional theory & Powell \& Di Maggio 1991 \\
\hline & Normative management & Bleicher 2009 \\
\hline & Non-traditional stakeholders & Jain et al. 2011 \\
\hline
\end{tabular}




\begin{tabular}{|l|l|l|}
\hline Networking and co-creation & $\begin{array}{l}\text { Network organisations and } \\
\text { learning }\end{array}$ & Knight 2002 \\
\cline { 2 - 3 } & $\begin{array}{l}\text { Organisational learning and } \\
\text { system improvement }\end{array}$ & Senge 1990 \\
\cline { 2 - 3 } & Soft systems methodology & Checkland \& Poulter 2006 \\
\cline { 2 - 3 } & Co-creation & $\begin{array}{l}\text { Payne et al. 2009; Prahalad } \\
\text { \& Ramaswamy 2004 }\end{array}$ \\
\hline
\end{tabular}

\section{Keeping the Vision Zero spirit alive}

There are several challenges and strategies for keeping the spirit of VZ alive. Here we will focus on three specific clusters of challenges.

1) The first of these is the impact of globalisation and the changing world of work (ILO, 2016; James, 2006). More specifically, the global financial situation stemming from around 2008 implies that cost reduction is a dominant factor, leading to a trend towards higher workloads, smaller HSW margins, growing job insecurity (causing stress but also less ownership and commitment to HSW) and challenges in the production chain (with contractors etc.).

The changing world of work also implies a range of other general challenges to the area of HSW. There is growing diversity with workforce migration, often implying different cultural backgrounds, languages and cultures. In addition, work teams are often changing rapidly due to contingent work. At the same time, there are generational gaps between young and older workers. This diversity can have severe implications for communication, education and training, cooperation, culture, and for dealing with personal vulnerabilities. In addition, it implies new forms of risk to worker HSW that impact on company sustainability (EU-OSHA, 2015). It is therefore important the companies commit to a wider VZ that includes these emerging priorities.

2) An additional ongoing challenge is reaching and engaging the many small and mediumsized enterprises that often do not have a long-term vision or policy in HSW. Larger VZ committed companies can play an important role in this respect by increasing the general 
business attention to HSW, and by motivating and supporting smaller enterprises that are their suppliers, contractors, customers or neighbours to commit to HSW goals. As VZ companies are highly ambitious, they are likely to recognise these generic challenges at an early stage, and to deal with them seriously and effectively. This is another reason why research into the practices of VZ companies is interesting and important.

3) Mainstreaming into business management is the third important challenge. The VZ message needs to go beyond individual HSW company departments, from the HSW community (including HSW policy makers) to business leaders. It is important in this respect to keep in mind that ZAV and ZH are usually part of a broader 'family of Vision Zero', e.g. zero defects, zero waste and traffic accidents, etc. (Zwetsloot et al., 2013, 2017a). Seeing ZAV, ZH and VZ in a broader setting was suggested also as an explanation for why ZAV was more easily accepted in industrial practice than in the safety science community (Zwetsloot et al., 2013a). These broader 'zero visions' often go beyond aspects of internal organisation, and may include the development of new products and services, e.g. Volvo and General Motors both claim to work on the development of 'zero crash cars', and they see it as a marketing incentive to work safe and produce safe products (Avila and Hosford, 2012; Volvo, 2017).

Singh (2012), an important business analyst, sees the broader VZ perspective, which he calls 'innovating to zero', as one of the ten Mega Trends that will impact business and society globally in the coming decade. Singh emphasises the innovative nature of VZ, its close relationship with running business, and describes it as a journey generating many opportunities along the way to creating and ensuring safety.

"The most remarkable feature of this Mega vision is that the ultimate opportunity lies not in attaining the actual goal itself, but in capitalising on the opportunities that would lead to it It also needs a strong culture from people within that ecosystem" (Sing, 2012, p. 59).

Clearly, this implies several challenges not only for the industry, but also for the HSW community at large. 


\section{Developing a full Zero Harm culture}

Genuine commitment to zero accidents or harm is a value laden commitment that has many implications for organisational culture. In the safety literature there continues to be a lot of attention to safety culture and climate and safety leadership (Petitta et al., 2017; Leitão et al., 2016; Clarke, 2013 and 2006), and there is growing attention to safety as a value (Ratilainen et al., 2016; Cooper, 2001). In the area of health and well-being there is a growing interest in organisational values, culture and leadership (e.g. NICE, 2015).

Organisations increasingly define core values to give meaning to the companies' existence and their value for society. When core values are more than a public relations instrument, they are important for the identity, and cohesion of organisations. Core values have the potential to guide the practices and behaviours of managers, supervisors, and workers.

From this perspective it is logical that there is growing attention to values that support safety (Ratilainen et al., 2016), and to the value of HSW. Again there are several values that are supportive of HSW (Zwetsloot et al., 2013b). In their broad literature review, Zwetsloot et al. (2013b) identified seven core values that are supportive to HSW, which could be clustered into three groups: 1) a value cluster characterized by a positive attitude towards people and their 'being' (comprising the core values of interconnectedness, participation and trust); 2) a value cluster relevant for organizational and individual 'doing' (comprising justice and responsibility); and 3) a value cluster relevant for 'becoming' which is characterized by the alignment of personal and organizational development (comprising the values of growth and resilience).

However, values can have a broader meaning related to work as well: values for doing 'meaningful' work (Milliman et al., 2003), and for being inspired, motivated and engaged through alignment of individual and organizational goals (Beer, 2009). These broader values also imply the development of a positive organisational culture, beyond safety culture. Olsen et al. (2015) showed that a positive organisational climate (broader than safety climate) can also be relevant for safety on oil platforms. 
Another challenge is the development and maintenance of a 'learning driven culture' for HSW (e.g. IAEA, 2016). This implies a learning attitude of management and workers, as well as a transition from 'We must work safe and healthy' to 'We want to work safe and healthy' (intrinsic motivation; Ryan and Deci, 2000).

One model that moves towards this more holistic HSW understanding is the 'Total Worker Health' approach which focuses on policies, programs and practices that integrate both 'protection' from OSH hazards and 'promotion' of injury and illness prevention in furthering wellbeing for a globally competitive workforce (Schill and Chosewood, 2013). A review of Total Worker Health interventions has shown preliminary and promising results of the integration of HSW promotion activities (Anger et al., 2015).

\section{Conclusion}

There is a steadily growing attention in industry for VZ in terms of a long term commitment process to strive for Zero Accidents and/or ZH. In most organisations the attention for safety is dominant, while health and wellbeing at work still receive much less attention. VZ should be regarded as a holistic vision, wherein health, safety and wellbeing at work are all addressed, and synergies between these areas are recognised and utilised. There is already sufficient evidence to state that fatigue, stress, and work organisation factors in general are important determinants of safety behaviour and performance. The broadening of ZAV to a $\mathrm{ZH}$ vision wherein wellbeing is addressed seriously is therefore an important challenge for many industries. The integration into business development and the development of a broader $\mathrm{ZH}$ culture (or prevention culture) are important challenges for VZ committed companies. There is a clear need for empirical research into this challenging area.

\section{References}

2nd Strategy Conference, 2011. Five Pillars for a culture of prevention in business and society. Strategies on Safety and Health at Work, 3-4 February 2011, DGUV Academy Dresden. Available at: http://www.dguv.de/iag/veranstaltungen/strategiekonferenz/2011/index-2.jsp (accessed 23-2-2017) 
Akerstedt T, Fredlund $\mathrm{P}$, Jansson B, 2002. Workload and work hours in relation to disturbed sleep and fatigue in a large, representative sample. Journal of Psychosomatic Research, $53,585-588$.

Anger, WK, Elliot, DL, Bodner, T, Olson R, Rohlman DS, Truxillo DM, Kuehl KS, Hammer LB, Montgomery D, 2015. Effectiveness of Total Worker Health interventions. Journal of Occupational Health Psychology, 20(2), 226-247.

Avila J, Hosford M, 2012. General Motors' super cruise technology aims to bring accident free car, ABC News, 17 September 2012. Available at: http://abcnews.go.com/Technology/general-motors-supercruise-technology-aims-bringaccident-free/story?id=17218793. Accessed 20 January 2017.

Baker J., 2007. The Report of the BP US Refineries Independent Safety Review Panel.

Barling J, Loughlin C, Kelloway KE, 2002. Development and test of a model linking safetyspecific transformational leadership and occupational safety. Journal of Applied Psychology, 87(3), 488-496.

Beer M, 2009. High Commitment, high performance - How to build a resilient organization for sustained advantage. Jossey -Bass, San Francisco.

Bergh LIV, Hinna S, Leka S and Zwetsloot GIJM, 2016. Developing and testing an internal audit tool of the psychosocial work environment in the oil and gas industry. Safety Science, 88, 232-241.

Bergh L.I.V., Hinna S., Leka S., 2014a. Sustainable business practice in a Norwegian oil and gas company: integrating psychosocial risk management into the company management system. In: Leka S., and Sinclair R.R. (editors), Contemporary Occupational Health Psychology: Global perspectives on research and practice, 3(1), Wiley \& Sons.

Bergh LIV, Ringstad AJ, Leka S, Zwetsloot GIJM, 2014b. Psychosocial risks and hydrocarbon leaks: An exploration of their relationship in the Norwegian oil and gas industry. Journal of Cleaner Production, 84, 824-830.

Bleicher K, 2009. Normatives und strategisches Management. Christian Abegglen, St Gallen Switzerland.

British Standards Institution (BSI), 2011. Guidance on the Management of Psychosocial Risks in the Workplace: PAS1010. British Standards Institution, London.

British Standards Institution (BSI), 2007. Occupational Health and Safety Management Systems: OHSAS 18001. British Standards Institution, London. 
Burnham JC 2009. Accident Prone - A history of Technology, Psychology, and Misfits of the Machine Age. University of Chicago Press, Chicago.

Chan M, 2011. Fatigue: the most critical accident risk in oil and gas construction. Construction Management and Economics, 29, 341-353.

Checkland P, Poulter J, 2006. Learning for Action: A Short Definitive Account of Soft Systems Methodology and its Use, for Practitioners, Teachers and Students. John Wiley and Sons Ltd, Chichester.

Christian MS, Bradley JC, Wallace JC, Burke MJ, 2009. Workplace Safety: A Meta-Analysis of the roles of person and situation factors. Journal of Applied Psychology, 94(5), 1103-1127.

Clarke S, 2013. Safety leadership: A meta-analytic review of transformational and transactional leadership styles as antecedents of safety behaviours. Journal of Occupational and Organizational Psychology, 86(1), 22-49.

Clarke S, 2006.The relationship between safety climate and safety performance: A metaanalytic review. Journal of Occupational Health Psychology, 11(4), 315-327.

Cooper D, 2001. Treating safety as a value. Professional Safety, February, 17-21.

Dahlbäck O, 1991. Accident proneness and risk-taking. Personality and individual differences, 12(1), 79-85.

Deci EL, Ryan RM, 2008. Self-determination theory: A macro theory of human motivation, development and health. Canadian Psychology, 49(3), 182-185.

Dekker SZW, 2015. The psychology of accident investigation: epistemological, preventive, moral and existential meaning-making. Theoretical Issues in Ergonomics Science, 16(3), 202-213

Dekker SZW, Pitzer, 2015. Examining the asymptote in safety progress: A literature review. International Journal of Occupational Safety and Ergonomics, published on line 14 December 2015.

Dekker SZW, 2014a. The bureaucratization of safety. Safety Science, 70, 348-357.

Dekker SZW, 2014b. Employees: A problem to control or solution to harness? Insurance newsnet.com. Newswires, 22 August 2014.

Dekker SZW, 2014c. The problems of Vision Zero in work safety. Malaysia Labour Review, $8(1), 25-36$ 
Dembe AE, Erickson JB, Delbos RG, Banks SM, 2006. Nonstandard shift schedules and the risk of job-related injuries. Scandinavian Journal of Work, Environment and Health, 32(3), 232240.

Dollard MF, Bakker AB, 2010. Psychosocial Safety Climate as a precursor to conducive work environments, psychological health problems, and employee engagement. Journal of Occupational and Organizational Psychology, 83, 579-599

Dollard MF, 2007. Psychosocial safety culture and climate: definition of a new construct. Adelaide, Work \& Stress Research Group of South Australia.

EC 2013. European Commission: Directive 2013/30/EU on safety of offshore oil and gas operations.

Edwards JRD, Davey J and Armstrong K, 2013. Returning to the roots of culture: A review and re-conceptualisation of safety culture. Safety Science, 55, 70-80.

Eeckelaert L, Dhondt S, Oeij, P, Pot FD, Nicolescu GI, Webster J, Elsler D, 2012. Review of workplace innovation and its relation with occupational safety and health. EU-OSHA, Bilbao.

Eichendorf W, Bollmann U, 2014. Future approaches to a culture of prevention. In: From Risk to Vision Zero - (Selected) Proceedings of the International Symposium on Culture of Prevention - Future Strategies, pp $43-53, \mathrm{FIOH}$, Helsinki.

EU-OSHA - European Agency for Safety and Health at Work, 2015. Second European Survey of Enterprises on New and Emerging Risks (ESENER-2). Luxembourg: Publications Office of the European Union.

EU-OSHA, 2010 (Pawlowska Z, Eeckelaert L editors). Mainstreaming OSH into business management. European Agency for Safety and Health at Work, Bilbao.

Flin R, O'Connor P, Crichton M, 2008. Safety at the sharp end - A guide to non-technical skills. CRC Press, Boca Raton.

Glasscock DJ, Rasmussen K, Carstensen O, Hansen ON, 2006. Psychosocial factors and safety behaviour as predictors of accidental work injuries in farming. Work \& Stress, 20(2), 173 189.

Goldenhar LM, Williams L, Swanson NG, 2003. Modelling relationships between job stressors and injury and near miss outcomes for construction labourers- Work \& Stress, 17 (3), 218-240. 
Griffin MA and Curcuruto M, 2016. Safety climate in organizations. Annual Review of Organizational Psychology and Organizational Behavior, 3, 191-212.

Groeneweg J, 1994. Controlling the controllable - the management of safety. DSWO Press, University of Leiden.

Grøtan TO, Waerø IO, Van der Vorm JKJ, Van der Beek FA, Zuiderwijk DC, Using gaming and resilience engineering training of front-end operators and managers, 2016. In Walls, Revie and Bedford (editors), Risk, Reliability and Safety: Innovating theory and Practice, pp 2246-2253, Taylor \& Francis.

Grote G, Kunzler C, 2000. Diagnosis of safety culture by safety management audits. Safety Science, 34, 131-150.

Grote G, Kunzler C, 1996. Safety culture and its reflections in job and organisational design: Total Safety Management. International Journal of Environment and Pollution, 6, 4-6.

Hollnagel E, 2014. Safety I and Safety II, The Past and Future of Safety Management. CRC Press, Boca Raton.

Hollnagel E, Woods DD, Leveson N, 2006. Resilience Engineering: Precepts and concepts. Ashgate, Aldershot.

IAEA 2016. Performing Safety Culture Self-Assessments. Safety Reports Series No 83 (annex 1), IAEA, Vienna.

ILO - International Labour Organization, 2016. Workplace stress: A collective challenge. Geneva: ILO.

Jain A, Leka S, Zwetsloot GIJM, 2011. Corporate Social Responsibility and Psychosocial Risk Management in Europe. Journal of Business Ethics, 101(4), 619-633.

James P, 2006. The changing world of work: an exploration of its implications for workrelated harm. Policy and Practice in Health and Safety, 4(1), 3-15.

Karasek RA, 1979. Job demands, job decision latitude, and mental strain: Implications for job redesign. Administrative Science Quarterly, 24(2), 285-308.

Knight L, 2002. Network learning: exploring learning by interorganisational networks. Human Relations, 55(4), 427-454.

Lamond N, Dawson D, 1999. Quantifying the performance impairment associated with fatigue. Journal of Sleep Research, 8(4), 255-262.

Larsson TJ, 2003. Who will use claims data for the prevention of occupational trauma? Safety Science Monitor, 7, Article III-3, pp 1-10. 
Laschinger S, Heather K, Leiter RN, Michael P, 2006. The Impact of nursing work environments on patient safety outcomes: The mediating role of burnout engagement. Journal of Nursing Administration, 36(5), 259-267.

Leitão S and Greiner BA, 2016. Organisational safety climate and occupational accidents and injuries: an epidemiology-based systematic review. Work \& Stress, 30(1), 71-90.

Leka S, Jain A, Zwetsloot G, Andreou N, Hollis D, 2016. Future challenges of occupational safety and health policy making in the UK. Policy and Practice in Health and Safety, 14(1), $1-16$.

Leka S, Van Wassenhove W, Jain A, 2015. Is psychosocial risk prevention possible? Deconstructing common presumptions. Safety Science, 71(1), 61-67.

Leka S, Jain A, 2010. Health impact of psychosocial hazards at work: an overview. WHO, Geneva.

Leka S, Cox T, Zwetsloot G, 2008. The European framework for psychosocial risk management. In: LEKA, S and \& COX, T., eds., The European framework for psychosocial risk management: PRIMA-EF Nottingham, I-WHO Publications.

Locke EA, Latham GP, 2002. Building a practically useful theory of goal setting and task motivation: a 35-year odyssey. American Psychologist, 57(9) 705-717.

Long R, 2012. The Zero Aspiration - The Maintenance of a dangerous idea. http://www.humandymensions.com/images/images/The\%20Zero\%20Aspiration\%20the\% 20Maintenance\%20of\%20a\%20Dangerous\%20Idea.pdf (accessed 28 January 2016).

Mathisen GE, Bergh LIV, 2016. Action errors and rule violations at offshore oil rigs: the role of engagement, exhaustion and health complaints. Safety Science, 85, 130-138.

Mearns K, Flin R, Gordon R, Fleming M, 2001. Human and organizational factors in offshore safety. Work \& Stress, 15 (2), 144-160.

Mendeloff J, Burns R, 2013. States with low non-fatal injury rates have high-fatality rates and vice versa. American Journal of Industrial Medicine, 56(5), 509-519.

Milliman J, Czaplewski AJ, Ferguson J, 2003. Workplace Spirituality and Employee Work Attitudes. Journal of Organizational Change Management, 16(4), 426-447.

Nahrgang JD, Morgeson FP, Hofmann DA, 2011. Safety at Work: A Meta-Analytic investigation of the link between job demands, job resources, burnout, engagement and safety outcomes. Journal of Applied Psychology, 96(1), 71-94. 
NICE - National Institute for Health and Care Excellence 2015. Workplace health: Management practices. UK: NICE guideline [NG13]. Available at: nice.org.uk/guidance/ng13

Oeij PRA, Rus D, Pot FD, (Eds.), in print. Workplace Innovation: Theory, Research and Practice, 'Aligning Perspectives on Health, Safety and Well-Being' series. Springer publishing company (in print, expected 2017).

Olsen E, Naess S, Høyland S, 2015. Exploring relationships between organizational factors and hydrocarbon leaks on offshore platform. Safety Science, 80, 301-309.

Parker SK, Axtell CM, Turner M 2001. Designing a safer workplace: Importance of Job autonomy, communication quality and supportive supervisors. Journal of Occupational Health Psychology, 6(3), 211-228.

Payne AF, Sorbacka K, Frow P, 2008. Managing the co-creation of value. Journal of the Academy of Marketing Science, 36, 83-96.

Petitta L, Probst TM, Barbaranelli C, Ghezzi V, 2017. Disentangling the roles of safety climate and safety culture: Multi-level effects on the relationship between supervisor enforcement and safety compliance. Accident Analysis \& Prevention, 99(A), 77-89.

Powell WW, DiMaggio PJ, 1991. The new institutionalism in organisational analysis. University of Chicago Press.

Prahalad CK, Ramaswamy V, 2004. Co-creation experiences: The next practice in value generation. Journal of Interactive Marketing, 18(3), 1-14.

Ratilainen Henriikka (ed.), Salminen S, Zwetsloot G, Perttula P, Starren A, Steijn W, Drupsteen L, Puro V, Räsänen T, Aaltonen M, Berkers F, Kalakoski V, 2016. The value of safety and safety as a value. Saf€ra Technical Report No 1, SAFERA.

Roberts KH, 1990. Some Characteristics of High-Reliability Organizations. Organization Science, 1, 160-177.

Rogers EM, 1993. Diffusion of innovations. Free Press, New York.

Ryan RM, Deci EL, 2000. Self-determination theory and the facilitation of intrinsic motivation, social development, and well-being. American Psychologist, 55, 68-78.

Salminen S, Lee J, 2015. A concept of a culture of prevention: A review of literature. Occupational Medicine and Health Affairs, 2:154.

Sharman A, 2014. From Accidents to Zero. Maverick Eagle Press, Great Britain. 
Shill AL, Chosewood LC, 2013. The NIOSH Total Worker Health program - an overview. Journal of Occupational and Environmental Medicine, 555(12), 8-11.

Senge P, 1990. The Fifth Discipline, The art and practice of the learning organisation. Doubleday, New York.

Singh S, 2012. New Mega Trends - Implications for our future lives. Palgrave Macmillan, Hamshire (UK), New York (US).

Sneddon A, Mearns K, Flin R, 2013. Stress, fatigue, situational awareness and safety in offshore drilling crews. Safety Science, 56, 80-88.

Twaalfhoven SFM, Kortleven WJ, 2016. The corporate quest for zero accidents: A case study into the response to safety transgressions in the industrial sector. Safety Science, 86, 5768.

Volvo 2017. Volvo sees crash free car by 2020.

https://www.cnet.com/roadshow/news/volvo-sees-crash-free-car-by-2020/, accessed 20 January 2017.

Weick KE, Sutcliffe K, 2007. Managing the unexpected. Jossey-Bass, San Francisco.

Williamson A, Lombardi DA, Folkard S, Stutts J, Courtney JK, Connor JL, 2011. The link between fatigue and safety. Accident Analysis and Prevention, 43(2), 498-515.

WSH, 2012. Towards Vision Zero - A guide for Business Leaders. WSH Institute, Singapore.

Young S, 2014. From Zero to Hero. A case study of industrial injury reduction: New Zealand Aluminium Smelters Limited. Safety Science, 64, 99-108.

Zohar D, 2014. Safety climate: Conceptualization, measurement, and improvement. The Oxford handbook of organizational climate and culture, 317-334.

Zwetsloot GIJM, Kines P, Wybo JL, Ruotsala R, Drupsteen L, Bezemer RA, 2017a. Zero Accident Vision based strategies in organisations: Innovative perspectives. Safety Science, $91,260-268$.

Zwetsloot GIJM, Kines P, Ruotsala R, Drupsteen L, Merivirta ML, Bezemer RA, 2017b. The importance of commitment, communication, culture and learning for the implementation of the zero accident vision in 27 companies in Europe. Safety Science, 96, 22-32.

Zwetsloot GIJM, Aaltonen M, Wybo JL, Saari J, Kines P, Op De Beeck R, 2013a. The case for research into the zero accident vision. Safety Science 58, 41-48.

Zwetsloot GIJM, van Scheppingen AR, Bos EH, Dijkman A, Starren A, 2013b. The Core Values that support Health, Safety and Well-being at Work. Safety \& Health at Work, 4, 187-196. 
Zwetsloot GIJM, Leka S, 2010. Corporate culture, health and well-being. In: Leka S, Houdmondt J, (Eds), A text book for Occupational Health Psychology, Chapter 9, pp 250268, Wiley - Blackwell, Chicester (UK).

Zwetsloot GIJM, Ashford NA, 2003. The feasibility of encouraging inherently safer production in industrial firms. Safety Science, 41(2), 219-240. 